\title{
SUPPORTING AND HINDERING FACTORS OF ONLINE TEACHING IMPLEMENTATION IN UNIVERSITAS MAHASARASWATI DENPASAR
}

\author{
N.L.P. Suryanti ${ }^{1}$, L.P. Artini ${ }^{2}$, M.H.Santosa ${ }^{3}$ \\ ${ }^{123}$ English Language Education, Universitas Pendidikan Ganesha, Singaraja \\ e-mail: ap3bali.pebri@gmail.com ${ }^{1}$, putu.artini@undiksha.ac.id ${ }^{2}$, ${\text { mhsantosa@undiksha.ac.id }{ }^{3}}^{2}$
}

\begin{abstract}
Online Learning was a learning approach that provides teaching and learning processes through the internet. The flexibility and accessibility made the learners could learn without limitation of time or place. In implementing an effective online learning process, supporting factors and hindering factors were important to be considered. This study aimed to describe supporting and hindering factors of online Learning. The approach used in this study was a mixed-method approach that employed explanatory sequential design. A questionnaire was used to collect the data. The participants were 35 instructors of Mahasaraswati University Bali. The result showed the supporting factors of the success of online Learning came from technological factor, quality of the system and content and human factors. The constraint were derived from lack of quality and poor accessibility in remote areas. Both supporting and hindering factors should be considered to get success of online Learning.
\end{abstract}

\section{Keywords: EFL Learning; Online Learning; Supporting and Hindering Factors}

\section{INTRODUCTION}

Online Learning is the newest and most popular form of distance education that takes place over the internet (Stern, 2018). White (2004) adds that online Learning is an approach where the online Learning, teaching, and learning process is actualized with the internet technology. According to Douglas and Van Der Vyver (2004), online Learning has received considerable attention as a means of providing alternatives to traditional face-to-face, instructor-led education. Online teaching offers a fast opportunity to expand the learning environment for diverse students' populations (Keengwe \& Kidd, 2010). The students will get various instructional aid and communication method from online Learning. It is because there is a wide set of technology engage in online Learning including computer based Learning, web based Learning, virtual classroom and digital collaborations (Urdan \& Weggen, 2000). J and Karen (2003) also add online Learning allow the students to participate regardless of geographic location, independent of time and place. According to Govindasamy (2001) online Learning is used interchangeably with e-learning. E-learning includes instruction delivered via all electronic media such as internet, intranets, extranets, and hypertext/hypermedia document. There are the following benefits of e-learning that was noted by Chen and Huang et al., (2007) as follows. First, its lower cost. Second, its content is more timely and dependable. Third, it is a just in time learning approach. Fourth, it builds universal communities. And the last, it provides an increasingly valuable learner service (Sanderson, 2002). E-learning is means for solving authentic learning and performance problem reported by (Govindasamy, 2001). Moreover, e-learning also creates benefits such as reduced cost, regulatory compliance, meeting business needs, retraining employees, low recurring costs, and customer-support costs (Gordon \& Gordon, 2003; Harun, 2002 ; Ismail, 2002).

The development of online Learning in higher education had been started in United States in the 1800's, the teacher and the students tried to connect through correspondence program because of their different locations (Marina \& Mclsaac et al., 2004). They also reported the development of the online Learning was improved year after. In 1981 the first fully online course was offered and the first online program was established by the Western Behavior Science Institute in the following year (Harasim, 2000). In the mid-1980 several universities and schools initiated the first online undergraduate and graduate courses. Marina et al., (2004) add the greatly faster growth of distance education was spurred due to a shortage of teachers on math, science, foreign languages and etc. Therefore, some $\mathrm{K}-12$ 
schools turned to commercial courses offered through the then-new-satellite technology in the late 1980s. The advent of the World-Wide Web (WWW) in 1991 was powerful for moving distance education forward, and was a milestone in the rapid expansion and growth of online teaching and Learning. Maloney-Krichmar and Preece (2005) states that WWW "facilitated the widespread use of web sites and the development of online community groups supported by web pages and various forms of communications software". Colleges and universities both in the United States and around the world have offered not only just online courses but entire degree programs online as well since then (Wallace, 2003). Bell and Federman (2013) point that the fast development of the Internet and World Wide Web (WWW) has produced numerous benefits to education. Online education provides potential opportunities to open up new markets for higher education institution. The flexibility of online Learning will make many adult learners enjoy when they have to balance work, study, and family responsibilities. Moreover, the nature of anonymity in the online learning environment may allow more students who do not want to attend face to face classes because of they do not have enough confidence to participate in online education because they do not physically see each other.

Huhtanen (2019) stated that by implementing the online Learning it will be beneficial because of the flexibility and saving time in online Learning. The flexibility of online Learning make the lesson available to those students which feel difficult to attend lectures at a specific time or location. Moreover, because it provides tools so the course can be delivered to a large number of students. He also adds high-quality of online Learning make a valuable contribution to Learning, it was shown in the studies. It is in line with Yuan \& Kim (2014) arguments who point out the benefit that the online learners get from the online Learning. First, because of the connectivity with one another, they are able to share their knowledge and fulfill common goals, which can reduce students' dropout rates. Second, the relationship and interaction between the instructor and learners and among peer learners can increase the student performances and their satisfaction of the course. Third, learners can receive supports and help from their peers at the same time they can add their knowledge base through their interactive actions. Online Learning is considered as a boon due to reasons such as accessibility, personalized Learning, develop cognitive abilities, cost-effectiveness, basic computer skills, equal opportunity to all, self-pacing, and globalization (Lead, 2011). Students can learn from anywhere no matter where students' live because accessibility that online Learning provides. Online learing has potential to motivate, develop confidence and self-esteem, overcome many barriers that learners ecounters. It beneficial for students personalized Learning. In the research of Panwar, Kumar, and Belsiyal (2019) it was found that e-learning may be effective in developing cognitive abilities of pupil teachers. The result found the students of e-learning program had higher achievement levels than their counterparts. Online learning cost is effective because the students do not need to study abroad and buying books. They just need to be have computer hardware and connected to internet. Students' computer skills can be improved because whole classes happen through ICT. All students are treated pairly without exception. Students who are disabled and face problem in communiting and for those who live at far off places where the schools or colleged feel online Learning as a boon. Online Learning allows students to work and learn at their own pace without time restriction. They can review the discussed material because not all students are able to understand the topic samely. And through online elarning students could be connected all over the world. Lead (2011) states instructional technology is highly beneficial for students, online Learning is considered a boon due to the reasons as follows. Students can learn from anywhere in the world due online Learning provides accessibility. It does not matter where the students live and what they want to study, they can still study. The students learning options are not constrained by their geographic location because of its accessibility. Personalized Learning means online learning system enables a student to determine and process his/her learning style, content, aim, current knowledge and individual skills. E-learning enables the individual to plan and direct his/her own Learning. It has the potential to motivate, develop confidence and self-esteem, overcome many barriers that learners encounters, personalize the learning experience widen access, and improve the learning experience while also helping people develop their ICT skills. In the research of Panwar, Kumar, and Belsiyal (2019), e-learning may be effective in developing the cognitive abilities of pupil teachers. The result found the students of the e-learning program had higher 
achievement levels than their counterparts. A student can find unlimited information which he can access just by the click of a button.

However, to succeed in its implementation, there are supporting factors that were needed and hindering factors that they were faced. This study took place in Universitas Mahasaraswati Denpasar. Based on preliminary study, it was found that this university has implemented online teaching. However, in its implementation, the teachers found some constraints that they faced. The major answers were because of pour of internet connection, as it is online teaching, the success of its implementation depends on it. The pour connection was happened in the students themselves as well as the teachers' connection. The other constraint that they faced was less focus of the students because they were easily being distracted by their surroundings. The teachers also mentioned there were some students who were lack of technological skill, they were sometimes needed help to control the online Learning, such as sharing screen, and used raising hand icon. In its implementation, the teacher also reported that the supported tools to support its implementation are needed. They mentioned the supported tools such as speaker, projector and best quality of internet provider. The students also needed to be supported by laptop as well as good quality of internet provider. Considering of this problem, the research was required to be conducted in order to know the others supporting and hindering factors that the teacher faced to get success of online teaching implementation. So, its implementation could run smoothly.

Ozkan and Koseler (2009b) explained six factors that support the success of it implementation, namely system quality, content quality, service quality, instructor attitudes, learner perspectives and supportive issues. System quality refers to quality of the functionality of an information system itself (DeLone \& McLean, 2003). Online Learning should be in the highest quality in terms of ease of use, ease of access, and flexibility as the most important factors. According to Wahab et al., (2010) service quality is judgement of a service that perceptions on service quality and ease-of-use contributes to custome satisfaction. Experinece in interacting or accessing the services play a vital role in ascertaining in finding out the level quality (DeLone \& McLean (2003). Encouraging learners' habit needs important aspects such as easy navigation, easy to find required information and available help information in order to have service quality (Ozkan \& Koseler, 2009). Service quality have been found out to have direct influence on user satisfaction in diverse context of information system (M.A.F. Osman et al., 2018). Whereas, content quality refers to the perceived output by the system include accuracy, relevance, timeless, sufficiency, completeness, understandability, format and accessibility (Seddon, 1997). Roca, Chiu, and Martínez (2006) state in the e-learning context it measured information quality by indicators related to relevance, timeliness, sufficiency, accuracy clarity and format, and proved that information quality directly significant on learner's satisfaction and indirectly on perceived usefulness. The instructors need to be aware in designing the content in order to get the effectiveness of online Learning in which students are willing to explore the qulity content for their Learning. And the last come from humant factors include learners' attitude, instructors' attitude, computer-literacy, teaching method and collaboration between library and faculties. Webster and Hackley (2014) states significant effect on online learning success depends on learners' attitude towards technology. The learners' attitude could have significant effect on online Learning in which there is self-explored, self-paced,a nd self-monitored learning system. Although online learning application is rich in their system quality,service quality and it content but the students' attitude is not right it moght be decreased the effectiveness of online Learning (M.A.F. Osman et al., 2018). Instructor is the most important success factor in online Learning where they can increase students' satisfaction and encouraged them to become engaged in various learning opportunities (Kim, Trimi, Park, and Rhee, 2012). Instructors play a vital role in helping students to achieve learning objectives. Instructors who are highly active using online learning system by providing fast response, motivation support, suggestion, and assessment can positively increase student satisfaction (Loh et al., 2016). Anderson (1982) define computer literacy as the ability to control program to computer for personal, academic and professional goals. Everyone should be prepared with basic knowledge of technology, as well as utilize it as a mean for getting educational aims to support the use of ICT in teaching and learning process as the growth of the need for ICT. In the line, M.A.F. Osman et al., (2018) also found that by having experience with ICT and 
virtual competence were two important elements that affected e-learning and had positive influence on its result. Another factor of human factors was also from instructors teaching method. Boumová (2008) defines teaching method as a procedure or process for attaining a goal or a systematic procedure, technique or a set of rules that often related to a science or art. Hošková-Mayerová and Rosická (2015) adds the teaching method is link directly to the course outcomes, therefore teaching method is equally important in the online learning program. By considering the teaching method in e-learning it will increase the overall effectiveness of education (M.A.F. Osman et al., 2018). Kim et al., (2012) reported that instructor's teaching method is the most important success factor in e-learning whereby instructors increase user satisfaction and encourage students to become engaged in various learning opportunities. Effective teaching method used by instructors could increase user engagement and increase the effectiveness. And the last human factors came from collaboration between library and faculties. Lawal and Akintunde (2014) report library always played a dynamic role in encouraging excellence in teaching, Learning and research by providing user education includes one-on-one basis in the use of manuals and guides with the aim to familiarize students with library services and facilities. Effective collaboration between the library, faculty, and management will promote a better approach to learning at the institution therefore university library should contribute in facilitating teaching and Learning by exposing the students to information retrieval skills. Another factor of the success of online Learning is reported by Hadullo, Oboko, and Omwenga (2018). They mention six factors namely course design, content support, social support, course assessment, institutional factors, and learner characteristics. Whereas ten factors are state by Alqahtani and Rajkhan (2020), student characteristics, instructors characteristics, learning environment, instructional design, support, information technology, technology knowledge, course, level of collaboration, and knowledge management.

In implementing online Learning there are also constraint that affect the success of its implementation. Some experts reported different hindering factors as follows. Lead (2011) reported poor communication, sense of isolation, frustration, lack of motivation, lack of funds, lack of quality and poor accessibility in Remote areas are the hindering factors. Poor communication happen between teacher and students because they do not have opportunities to have face-to-face interaction with the teacher. Teacher may have detrimental effect on teaching and learning process as well as students' outcomes due to misinterpretation of tasks. Students are tendency to have feeling of isolation as they just in touch through social media and educational platforms. This feeling of isolation is a huge factor that prompted students to get fail. The students who find difficult in time management and tendency of procrastination and get lack motivation during studying will effect the students' success. The downsides of technology are include cost, hardware issues, internet problems, production of course materials and worry about availability of funds (Galusha, 1997). Lack of quality of online Learning also happen because instructors tent not wellprepared of the lesson seriously it affect the quality of online Learning. Online Learning cannot achieve its objective because some people do not have access to a computer and internet connection as important part in online learning implementation. Meanwhile Hadullo et al. (2018) reported that the factors that can hinder the success of online Learning is coming from institutional factor. The barriers and opportunities of e-learning implementation in Iraq it was because lack internet bandwidth, insufficient financial, inadequate training program, lack of technical support, lack infrastructure, ambiguous plan and policies and lack of interest and motivation (Al-Azawei, Parslow, \& Lundqvist, 2016). Similarly, the finding confirmed by Kituyi, Mayoka, and Kyeyune, 2012) observed the lack of computers and software for implementing e-learning, lack of e-learning skilled staff in universities, lack of policy and guidelines for using e-learning in universities, lack of government support for e-learning projects, high cost of telecommunication services and lack of resources for implementing elearning projects were the main quality issues in e-learning adoption in Uganda. Moreover, Mtebe and Raisamo (2014) on the challenges of instructors' intention to adopt and use open educational resources in higher education in Tanzania observed that inadequate ICT infrastructure, a low level of internet connectivity and an inadequate number of computers were the hindrance factor. This study proposed to describe supporting and hindering factors that instructors in Mahasaraswati University Bali faced in implementing online Learning. 


\section{RESEARCH METHOD}

The research used a mixed-method approach which employed explanatory sequential design. This study took place in Universitas Mahasaraswati Denpasar. The research participants were $35 \mathrm{EFL}$ instructors in that university. The educational qualification of the instructors in Universitas Mahasaraswati Denpasar has also fulfilled the requirement of being a lecturer. They were professors, doctors, doctorate candidates and magister with many experiences in the respective fields. Questionnaire was used to collect the data in form of google form. It employed Likert scale with consists of 5 points, (1) strongly disagree, (2) disagree, (3) undecided, (4) agree, and (5) strongly agree. Before the instruments were mainly administered, procedural tests were carried to find out the level of content validity, empirical validity and the reliability. The data of the instrument from the try out was also gained to know the empirical validity. The data was analyzed by using Microsoft Office Excel Program to attain the Pearson Product Moment in which the critical value r-table was 0.396. The reliability of the instrument were analyzed by using SPSS 12.0 program in order to gain Cronbach Alpha. The result showed the reliability coefficient of teacher's questionnaire was 0.942, meaning that the instrument was very high and reliable. The result of instruments was analyze by using Gregory's formula. It showed that the content validity was 1.00 , it can be inferred that the instrument was valid. In describing data analysis the study used Miles and Huberman (1994) design consisted of four steps namely data collection, data reduction, data display, and conclusion drawing and verification.

\section{FINDINGS AND DISCUSSION}

Instructors' responded in Mahasaraswati University Bali of close-ended questionnaire of supporting factors in implementing online Learning were calculated. Before delievered the questionnaire, it was tried out to fifteen instructors in that university and the result was examined by the content, empirical validity and realibility. To check the content validity, this study used Gregory formula. Thus, based on the result of Gregory formula, it was found that the content validity of of the instrument was 1 that was classified as very high qualification. It meant the instrument can be used as the test to collect the data.

Emperical vailidity was also gained after the instrument was tried out. The data analyzed by using Microsoft Office Excel Program to attain the Pearson Product Moment and the critical value r-table was 0.396 . Moreover, the instrument were also analyzed by using SPSS 12.0 program in order to gain Cronbach Alpha. The result of the questionnaire was 0.942 it meant the instrument was very high and reliable to gather the data.

The study followed Ozkan and Koseler (2009) to classify the items of supporting factors of online Learning. It consisted of 4 items, technological factors, system quality, service quality, content quality and human factors. Items on human factors such as learner's attitude, instructor's attitude, computer literacy, teaching method, collaboration between library and faculties.

1. Technological Quality

Instructors' response of supporting factors on online Learning which was technological quality, showed strongly agreed. The result showed $100 \%$ of instructors strongly agreed with the statement of technological quality which was "the quality of platform that is used should be good in supporting online learning". It inferred that effective implementation of online Learning supported from the quality of the platforms used as all the learning process conducted through the platforms. It should support the online learning process, from the start until last to get success in implementing online Learning.

2. System Quality

The result from instructors' respond showed $100 \%$ of instructors strongly agree with the quality of the system. Concerning the system quality, instructors strongly agreed with the statement "the quality oof the system of online learning should be easy to be used, accessed and flexible". It inferred that online Learning could run effectively in its implementation through the quality of the system itself. That should be easy to be used, accessed and flexible for both instructors and students. 
3. Content Quality

The result of content quality as supporting of online Learning also showed strongly agreed from instructors' response on the statement of "the important factor of online learning are accuracy and clarity of the material". It indicated that teacher have doubt to prepare the content of learning with good quality from the accuracy and clarity of the material. So the online Learning could be successful and increase the students' achievement.

4. Human Factors

The result average of human factors showed based on instructors' response showed that $81 / 17 \%$ strongly agreed, $18.52 \%$ agreed, and $0.29 \%$ unsure about the statement of the human factors. The majority of the instruuctors strongly agreed $(100 \%)$ with the statement of instrcutors' motivation also become important for the students' attitude in online Learning, the students' attitude towards Learning become part of the suvvess of online Learning, students' assignment should be given clear explanation about the criteria and due date, and stduents activeness is shown when the Learning is supported by discussion forum provided by teacher after explanation. Those finding indicated that teachers mostly believe that the success of online learning structure implementation mostly depends on teachers' to facilitate the online learning process so the students could show positive attitude and achievement and the in the second part is depend on the students How the students gave positive attitude towards their Learning and also their skill in using technology especially in online Learning. Where the lesson fully happen though online. On table 4.4 also showed that most of the teacher agreed with the statement of the rule of school library in providing books and references of online learning improvement supports the success of online Learning $(95 \%)$. It indicated that the school library also took important part on the success of online learning structure implementation. By providing books about online learning improvement, the teacher could use it as their references and also preparation for their online learning structure implementation. Overall, this human factors provided an outlook that supported factors from the teachers, students and also school library affect the success of online learning structure implementation.

In implementing online Learning there were also contrsints that instructors face to get success. The study followed Lead (2011) items were used to classify hindering factors of online Learning. There were 6 items such as poor communication, feeling isolated, lack of motivation, lack of funds and lack of quality.

1) Lack of fund

The result of close-ended questionnaires on hindering factors which was lack of funds showed $67.5 \%$ strongly agree, $28.75 \%$ agree, and $3.75 \%$ unsure. The most statement that instructors mostly agreed with is "instability of internet" $95 \%$. It was followed by the statement of "inaccurate internet access selection" it took $90 \%$. Both statements indicated that instructors believed the most constraint of online learning implementation was internet connection. Moreover, few teachers showed agree toward the statement of "lack of supported facilities such as computer, speaker, and LCD" that showed $90 \%$. It indicated that the constraint of the implementation of online Learning not only from internet but also from supported facilities. This finding revealed that role of internet as well as the supported facilities in the success of online learning implementation is demanded.

2) Lack of quality

Instructors' response of the statement of lack quality as the hindering factors of online Learning showed that $87.5 \%$ strongly agree, $7.5 \%$ agree, $2.5 \%$ unsure, and $1.25 \%$ disagree and strongly disagree from the average of the result. The most statement that instructors mostly agreed with was lack of computer and technological skill of the teacher (95\%). It inferred that instructors, as a vital role in implementing online Learning should be able to use technology. Because it was online Learning, the lesson mostly happens through the support of technology. However, quite few teachers unsure about "inadequate online learning preparation and bad quality of material." Thus, the role of instructors to have good quality is demanded. 
3) Poor Accessibility in Remote Areas

Instructors' responses on poor accessibility in remote areas were all positive. It clearly showed that the teacher strongly agreed that the unconducive area got $95 \%$. It indicated that the success of online Learning depends on the area where instructors and students are. The internet connection would be unstable when they live in a remote area.

4) Lack of motivation

The average of lack of motivation statements of lack of motivation showed $83.33 \%$ strongly agree, and $16.67 \%$ agree. Instructors showed high agreement on the statement "students' commitment and motivation in learning are hindering factors of online learning" got $90 \%$. Whereas, "teachers' commitment and attitude and lack of motivation given in using the technology" $80 \%$ strongly agree. The result showed most instructors agreed that lack of motivation from instructors and also students affect the success of online learning implementation.

5) Feeling isolated

The result of instructors' responses showed on average that $47.5 \%$ strongly agree and agree with the statement of feeling isolated. High agreement of instructors' response was shown on the statement of "students' depression because they could not get touch with the teacher and friends" in $85 \%$.

As a result of this study, it described the success of online learning implementation should be supported by supporting factors. The supporting factors that instructors' responses were from four factors, namely technological quality, system quality, content quality and human factors. The major responses that teachers strongly agreed of supporting factors were in system quality, service quality and human factors. The teachers had to make sure the quality of the system should be easy to be used, access and flexible. Moreover, the platforms that was used should be good so online Learning could run smoothly. It was because the learning process was conducted through the platforms. Other supporting factors that the teacher strongly agreed was content quality. The content, which was material of online Learning should be clear to make the students easy to understand.

Besides, human factors consisted of learners' attitude, instructors' attitude, computer literacy, teaching method and collaboration between library and faculties. Teachers strongly agreed that students' motivation and attitude towards Learning become parts of the success of online Learning. The learner's attitude could have a significant effect on e-learning if there are self-explored, self-paced, and self-monitored learning system. Although e-learning application might rich in their system quality, service quality and it content but the student's attitude is not right it might be decreased the effectiveness of e-learning (M.A.F. Osman et al., 2018). In addition, the success of online Learning also came from instructors' attitudes, the way instructors' motivated the students, used clear and interesting material, proper assignments to monitor students' progress, and provided feedback of students' assignments to motivate students' improvement. Kim, Trimi, Park, and Rhee (2012) stated that instructor is the most important success factor in e-learning whereby he/she increases user satisfaction and encourages students to become engaged in various learning opportunities. Computer literacy is the ability to control and program to computer for personal, academic and professional goals (Anderson, 1982). Teachers' strongly agreed the students and instructors' computer and technological skill helped the successful process of online Learning. Teachers put $100 \%$ with the statement of students with good technological skill were more interested and motivated in online Learning. This was confirmed by the study of (Hošková-Mayerová \& Rosická, 2015). Students with basic computer skills will feel more interested and motivated to use e-learning. However, the students with no basic computer skills will feel more difficult to get engaged as they need to learn how to use the application first. Moreover, teaching method that was used by the teacher is important to increase students' satisfaction and encourage students to become engaged in various learning opportunities. Teachers agreed with the statement of supported media such as good video, and the use of radio recording could improve the students' interest as well as a focus during the lesson. By considering the teaching method in e-learning, it will increase the overall effectiveness of education (M.A.F. Osman et al., 2018). The last aspect of human factors was a collaboration between libraries and faculties. Effective collaboration between the library, faculty, and management will 
promote a better approach to Learning. Teachers showed their agreement by providing books and references supporting the success of online Learning. It indicated that to make effective and successful teaching and learning process, there were supporting factors that instructors needed to take into consideration. The finding was similar to the result that was found by Joel S Mtebe and Raphael (2021). It indicated that instructors need to make sure of factors that help instructors' to make effective online Learning as well as it could get a positive effect.

Moreover, it also showed in its implementation there were some constraints that the instructors faced, such as lack of funds, lack of quality, poor accessibility in remote areas, lack of motivation, and feeling isolated. The major answered came from two aspects which were poor accessibility in remote areas and lack of quality. Online Learning is a learning process that is actualized with the internet (White , 2004). Teachers showed strongly agreed with the poor accessibility in remote areas as the constraint in online Learning because it could run smoothly without an internet connection. Another constraint noted by the teachers was the lack of quality. The average of some statements of its aspects was $87.5 \%$. The teachers noted inadequate online learning preparation, lack of computer and technological skills, bad quality of material, and difficulty uploading the material in the system. From the result, it could be inferred that there were some constraints in implementing the online teaching process. The result is similar as Zidat and Djoudi (2010) research findings which found that the biggest constraint of the success of online teaching was from service quality which was internet access. However, in this research, there were also found another constraint besides internet access in implementing online teaching. Therefore, it can be concluded the success of online learning implementation also have some constraints that teacher needed to be considered. By considering the supporting and hindering helped the teacher to be more prepared and get ready for their online teaching. It made the teaching and learning process could run smoothly.

\section{CONCLUSION AND SUGGESTIONS}

This study focused on describing supporting and hindering factors of online learning implementation in Universitas Mahasaraswati Denpasar. Based on teachers' responses on the questionnaire, most of the teacher put variety of responses on supporting factors that were coming from three factors such as, system quality, content quality and human factors. In his research, it was found the success of online teaching were coming from service quality, system quality and instructor quality. It became instructors concern to make sure teaching process could run smoothy by aware of supporting factors as part of the key success of online teaching process.

Nevertheless, there were hindering factors that confronted by teachers in implementing online teaching. The teachers' responses explained that the teachers agreed that hindering factors came from 4 aspects which were lack of funds, lack of quality, poor accessibility in remote areas, lack of motivation and feeling isolated. Based on the finding, the researcher also provides three suggestions that can be explained as follows: 1) For the instructor in implementing online Learning needs support from many aspects such as technological factor because it is online Learning so most of the lesson happens by support from technology. The teacher also need to think about the quality of the system, and teachers need to make sure that the system is in good quality so the online Learning could run smoothly. The important aspect also from the quality of the content, it focuses on the accuracy, relevance, timelessness, sufficiency, understandability, and accessibility of the material. And human factors also become crucial of the success of thriving online learning structure implementation. It comes from the role of the teacher, student, and also from the school. Certainly, the role of the teacher, students and school are needed. Moreover, teachers also need to consider the hindering factors that they might be facing, so they could prepare well about their online learning structure. Thus, they could have well-structured online Learning and can be implemented effectively. By having well structure online Learning make the learning process more active and efficient. Moreover, it also could affect the students' achievement. 2) School should put more attention in providing supporting facilities to support online learning implementation such as LCD, laptop and speaker. School library also need to provide book or references of teaching and learning process as well as in 
implementing online Learning. 3) It also suggested that this study could become a reference for other researcher who were interested in the same topic. Moreover, the researcher could explore more about supporting factors and hindering factors in terms of the effect of students' achievement and motivation to enrich the other previous study.

\section{ACKNOWLEDGEMENT}

The writers' gratitude went to several parties. First and foremost, the rector, director of postgraduate program, and the head of English post graduate program of Universitas Pendidikan Ganesha who facilitated and supported her to accomplish the study. Second, supervisors and all lecturers in English post-graduate program in Universitas Pendidikan Ganesha. Third, the head of English study program and instructors oin Mahasaraswati University Bali for giving permission to collect the data in this study.

\section{REFERENCES}

Al-Azawei, A., Parslow, P., \& Lundqvist, K. (2016). Barriers and opportunities of e-learning implementation in Iraq: A case of public universities. International Review of Research in Open and Distance Learning, 17(5), 126-146. https://doi.org/10.19173/irrodl.v17i5.2501

Alqahtani, A. Y., \& Rajkhan, A. A. (2020). E-learning critical success factors during the covid19 pandemic: A comprehensive analysis of e-learning managerial perspectives. Education Sciences, 10(9), 1-16. https://doi.org/10.3390/educsci10090216

Anderson. (1982). Computer Literacy: Rationale, Definition and Practices. 286.

Bell, B. S., \& Federman, J. E. (2013).DigitalCommons @ ILR E-Learning in Postsecondary Education E-Learning in Postsecondary Education.

Bennet, S., Priest, A.-M., \& Macpherson, C. (1999). Learning about online Learning: An approach to staff development for university teachers. Australasian Journal of Educational Technology, 15(3), 207-221. https://doi.org/10.14742/ajet.1858

Boumová, B. V. (2008). Faculty of Arts Department of English and American Studies English Language and Literature Traditional vs . Modern Teaching Methods: Advantages and Disadvantages of Each Master's Diploma Thesis. 11.

Chen, H., Hu, G., \& Huang, Z. (2007). Effective moduli for micropolar composite with interface effect. International Journal of Solids and Structures, 44(25-26), 8106-8118. https://doi.org/10.1016/j.ijsolstr.2007.06.001

DeLone, W. H., \& McLean, E. R. (2003). The DeLone and McLean model of information systems success: A ten-year update. Journal of Management Information Systems, 19(4), 9-30. https://doi.org/10.1080/07421222.2003.11045748

Douglas, D. E., \& Van Der Vyver, G. (2004). Effectiveness of E-learning course materials for learning database management systems: An experimental investigation. Journal of Computer Information Systems, 44(4), 41-48. https://doi.org/10.1080/08874417.2004.11647594

Galusha, J. (1997). Barriers to Learning in Distance Education. Interpersonal Computing and Technology Journal, 5(3), 6-14.

Gordon, J., \& Gordon, J. (2003). ResearchOnline @ Avondale One to One Teaching and Feedback One to one teaching and feedback. 326, 543-545. https://doi.org/10.1136/bmj.326.7388.543

Govindasamy, T. (2001). Successful implementation of e-Learning Pedagogical considerations. Internet and Higher Education, 4(3-4), 287-299. https://doi.org/10.1016/S1096-7516(01)00071-9

Hadullo, K., Oboko, R., \& Omwenga, E. (2018). Factors affecting asynchronous e-learning quality in developing countries. A qualitative pre-study of JKUAT University. International Journal of Education and Development Using Information and 
Communication Technology (IJEDICT), 14(1), 152-163.

Harasim, L. (2000). Harasim2000. Internet and Higher Education, 3, 41-61.

Harun, M. H. (2002). Integrating e-Learning into the workplace. 4, 301-310.

Hošková-Mayerová, Š., \& Rosická, Z. (2015). E-Learning Pros and Cons: Active Learning Culture? Procedia - Social and Behavioral Sciences, 191, 958-962. https://doi.org/10.1016/j.sbspro.2015.04.702

Huhtanen, A. (2019). the Design Book for Online Learning. The Design Bool for Online Learning.

Ismail, J. (2002). The design of an e-learning system Beyond the hype. 4, 329-336.

J, R. and, \& Karen, S. (2003). Elements of effective communication-Rediscoveries from homeopathy. Patient Education and Counseling, 77(2), 172-178. https://doi.org/10.1016/j.pec.2009.03.021

Keengwe, J., \& Kidd, T. (2010). Towards best practices in online Learning and teaching in higher education. ... Journal of Online Learning and Teaching, 6(2), 533-541. https://doi.org/http://dx.doi.org/10.1108/17506200710779521

Kim, K., Trimi, S., Park, H., \& Rhee, S. (2012). The Impact of CMS Quality on the Outcomes of E-learning Systems in Higher Education: An Empirical Study Subject Areas: CMS Benefits, Course Management System (CMS), E-learning, E-learning Success, Information Quality, Instructional Quality, User Satisfact. Decision Sciences Journal of Innovative Education, 10(4), 575-587.

Kituyi, G., Mayoka, \& Kyeyune, R. (2012). An analysis of E-learning information system adoption in Ugandan Universities: Case of Makerere University business school. Information Technology Research Journal, 2(1), 1-7. https://www.researchgate.net/profile/Geoffrey_Kituyi/publication/258725320_An_Anal ysis_of_E-

learning_Information_System_Adoption_in_Ugandan_Universities_Case_of_Makerer e_University_Business_School//inks/00b7d528df2612d143000000.pdf

Lawal, V., \& Akintunde, S. (2014). E-learning and information literacy at the University of Jos. Library Management, 35, 607-628. https://doi.org/10.1108/LM-07-2013-0062

Lead, J. (2011a). Online Learning. May, 1-3.

Lead, J. (2011b). 在线学习 (Online Learning). May, 1-3.

Loh, C., Wong, D. H., Quazi, A., Philip, R., Loh, C., Wong, D. H., Quazi, A., Philip, R., Alonderiene, R., Majauskaite, M., Rasheed, M. I., Humayon, A. A., Awan, U., Li, L., Hallinger, P., \& Ko, J. (2016). Article information:

M.A.F. Osman, Abdulwahid, K., \& Zakaria, A. (2018). Assessment of Factors Affecting Elearning: Preliminary Investigation. ResearchGate, August, 12.

Maloney-Krichmar, D., \& Preece, J. (2005). A multilevel analysis of sociability, usability, and community dynamics in an online health community. ACM Transactions on ComputerHuman Interaction, 12(2), 201-232. https://doi.org/10.1145/1067860.1067864

Marina, B., Mcisaac, S., \& Gunawardena, C. N. (2004). Distance Education. 1996.

Miles, M., \& Huberman, M. (1994). An analytic approach for discovery. In CEUR Workshop Proceedings (Vol. 1304, pp. 89-92).

Mtebe, J. S., \& Raisamo, R. (2014). Challenges and instructors' intention to adopt and use open educational resources in higher education in tanzania. International Review of Research in Open and Distance Learning, 15(1), 249-271. https://doi.org/10.19173/irrodl.v15i1.1687

Ozkan, S., \& Koseler, R. (2009). Multi-dimensional students' evaluation of e-learning systems in the higher education context: An empirical investigation. Computers and Education, Jurnal Pendidikan Bahasa Inggris Indonesia | 54 
53(4), 1285-1296. https://doi.org/10.1016/j.compedu.2009.06.011

Panwar, P., Kumar, R., \& Belsiyal, X. (2019). Loneliness, sociability and depression in old age home elderly. International Journal Of Community Medicine And Public Health, 6(10), 4331. https://doi.org/10.18203/2394-6040.ijcmph20194490

Roca, J. C., Chiu, C. M., \& Martínez, F. J. (2006). Understanding e-learning continuance intention: An extension of the Technology Acceptance Model. International Journal of Human Computer Studies, 64(8), 683-696. https://doi.org/10.1016/j.ijhcs.2006.01.003

Sanderson, P. E. (2002). E-Learning: strategies for delivering knowledge in the digital age. The Internet and Higher Education, 5(2), 185-188. https://doi.org/10.1016/s10967516(02)00082-9

Seddon, P. B. (1997). A Respecification and Extension of the DeLone and McLean Model of IS Success. In Information Systems Research (Vol. 8, Issue 3, pp. 240-253). https://doi.org/10.1287/isre.8.3.240

Stern, J. (2018). Introduction to Online Teaching and Learning. International Journal of Science Education, 3, 1-10. https://doi.org/10.1002/9781118784235.eeltv06b

Urdan, T. a, \& Weggen, C. C. (2000). Corporate E-Learning: Exploring a New Frontier. Analysis, 88. http://wrhambrecht.com/research/coverage/elearning/ir/ir_explore.pdf

Wahab, S., Nor, A. M., \& Al-Momani, K. (2010). The relationship between E- service quality and ease of use on Electronic Customer Relationship Management (E-CRM) performance: An empirical investigation in Jordan mobile phone services. IC4E 2010 2010 International Conference on e-Education, e-Business, e-Management and eLearning, 368-372. https://doi.org/10.1109/IC4E.2010.113

WALLACE, R. M. (2003). Online Learning in Higher Education: a review of research on interactions among teachers and students. In Education, Communication \& Information (Vol. 3, Issue 2). https://doi.org/10.1080/14636310303143

White, C. (2004). Independent Language Learning in Distance Education: Current Issues. Learning, September, 1-9.

Yuan, J., \& Kim, C. (2014). Guidelines for facilitating the development of learning communities in online courses. Journal of Computer Assisted Learning, 30(3), 220232. https://doi.org/10.1111/jcal.12042 